\section{B A Institute of \\ YK Business Administration \\ 帘 \\ Karachi \\ Leadership and Ideas for Tomorrow}

Business Review

Volume 10 Issue 2 July-December 2015

7-1-2015

\title{
Sikandar in Persian literature: Narcissistic leadership in childhood and adolescence
}

Naheed P. Malbari

nil

Follow this and additional works at: https://ir.iba.edu.pk/businessreview

Part of the Leadership Studies Commons

(c) (1)

This work is licensed under a Creative Commons Attribution 4.0 International License.

\section{Recommended Citation}

Malbari, N. P. (2015). Sikandar in Persian literature: Narcissistic leadership in childhood and adolescence. Business Review, 10(2), 170-187. Retrieved from https://doi.org/10.54784/1990-6587.1361

This article is brought to you by iRepository for open access under the Creative Commons Attribution 4.0 License and is available at https://ir.iba.edu.pk/businessreview/vol10/iss2/12. For more information, please contact irepository@iba.edu.pk. 


\title{
LITERARY NOTE
}

\section{SIKANDAR IN PERSIAN LITERATURE: NARCISSISTIC LEADERSHIP IN CHILDHOOD AND ADOLESCENCE}

\author{
Naheed P Malbari
}

\section{Abstract}

This paper is a hermeneutic phenomenological study of Sikandar, also known as Alexander the Great, from the point of view of two Persian texts interlaced with Plutarch's version. It explores the lived experience of the childhood of Sikandar on the one hand via the texts of Firdawsi and Nizami Ganjavi and on the other, explores the concept of narcissism in childhood and early adolescence in Persian Literature. Thus seven areas of narcissism were analysed namely grandiose self, high levels of activity, histrionic tendencies, impulsivity, antagonistic interpersonal stance, strong supportive mother and frustrated ambition of parents. As a prelude to a much larger study, this paper hopes to see the impact of certain characteristics of narcissism in childhood and early adolescence as given by the authors so as to gain an understanding that such concepts were delved into by medieval authors in poetic and other forms. Understanding leaders both ancient and modern is a complex phenomenon. To comprehend their childhood and explore it as a social construct and analyse its impact on leaders is of concern to social scientists in the $21^{\text {st }}$ century.

Keywords: Hermeneutic phenomenology, narcissism, childhood

\section{Introduction}

'Examining ancient leaders won't give us point-by-point guides that guarantee success, but it will give us real-life lessons... '(Forbes and Prevas, 2009, 10)

\subsection{Background of the Study}

Alexander of Macedon, known to the western world as 'great' and in the East known as Sikandar has been the subject of many a book and treatises. His vision of conquering the world has had a legendary quality to it and many a Romance has been written on him and his exploits. Greek, Egyptian, Islamic, Medieval European and Persian literature has him as a topic of discussion. Numerous history/biographical books (e.g. Cartledge, 2005; Green, 1992; Bosworth, 2000) leadership books (e.g. Bose, 2003; Forbes and Prevas, 2009; Sheppard, 2008; Martino, 2008) articles (e.g. Brunwasser, 2011; Borza 1998) research papers (e.g. Southgate, 1977; Jasnow, 1997), and media (Rossen's 1960's played by Burton and Stone's 2004 played by Farrell) have rendered Sikandar in all his 'infinite variety'. Usually Sikandar has been viewed from a Western framework where the cultural manifestations and reviewship traditions of writers of Sikandar's history (i.e. the Vulgate tradition which portrays him in a dark/negative shade as a tyrant or worse (e.g. Quint, 1982) and Apologetic traditions where Sikandar is depicted in a positive manner as a world leader (e.g. Robinson, 1947) and the East/West dichotomy come into play.

From the Eastern perspective, two traditions have been employed. Western writers viewing an eastern text on Sikandar bring into play numerous characteristics that depict their own historical context and their own Western medieval historiography. Eastern writers feel it 
important to view such texts from a classical Muslim civilization paradigm which is in no way medieval from the European context. For them such a writer 'thrived during the most vibrant period of scientific and intellectual activity throughout the Muslim world' (Omidsalar, 2011, p.g.30).

Also in the recent decades, the central principle has been to understand leaders and leadership research from a wide variety of traditions. Once again two main patterns have emerged. On the one hand, an attempt has been made to understand 'good' and 'effective' leadership with a divergence of models ranging from 'trait' approaches of leadership to 'complexity' theories. On the other end of the spectrum 'destructive' 'narcissistic' and the 'dark' side of leadership has been the subject of research.

Therefore, in this paper, a slightly differing paradigm has been used to understand a leader. Each leaders' life is a text and to analyse a text, a hermeneutic phenomenological mind-set might open up a differing dimension of analysis. Coming to the main paradigm of this paper, the childhood of a leader can also be seen as a text that can affect the leader in later life. In the case of Sikandar, his life has been a creation of multiple writers, a fusion of myth and reality, both historical and literary and can thus be an object of debate as to their authenticity and reliability. However, one can equally debate that in reality all leaders have treatises written about them which may or may not be totally true or relevant to their lives and sociologists and others analyse and scrutinize these documents. Thus analysing a historical/literary character like Sikandar makes this research equally relevant and justifiable.

\subsection{Problem Statement}

To ascertain the fact that Medieval Persian Literature can be relevant as a source of knowledge keeping in mind contemporary concepts in narcissistic leadership studies.

- To understand as to what extent 'Sikandar' (Alexander) had tendencies towards narcissism in his childhood/adolescence in Persian Literature

- To compare such tendencies with Plutarch's version

\subsection{Objectives of Study}

The researcher explores the concept of childhood experiences affecting narcissism in well known volumes of Persian Literature keeping in mind the current concepts of narcissism.

- To understand that ancient texts can bring forth and depict such narcissistic qualities

- To denote that contemporary concepts can be applicable to medieval literature

\subsection{Justification of study}

Only recently has humanities been the focus in leadership studies with the Leadership Quarterly having a special issue to this effect, where leadership was reviewed and studied from a non-empirical base. Yet, the pioneer of such work has to be attributed to the work of Weber $(1946,1968)$ who focused on charisma, keeping the religious dimensions in mind. A recent attempt by Warner (2007) in the Leadership Quarterly takes into account the cinematic presentation of Henry V play by William Shakespeare by two different directors and the emphasis is on the paradoxes of a leader. Also a previous study depicting the concept of Narcissism on the JISR titled 'Self Love: Shakespeare in film -Othello and Omkara' (Malbari, 2007) too, viewed a similar concept. 
Thus the focus of the study is to promote scholarship in the arts with a crossdisciplinary approach in leadership, in this case hermeneutic phenomenology from the philosophical dimension, narcissistic leadership from the social science perspective and a humanities subject like literature.

The question here arises as to what one can learn or hope to achieve from such a research. Recently ancient manuscripts have been used by numerous researchers to understand leadership or warfare. Examples of Sun Tzu's Art of War, is one such manuscript which has been analyzed in many ways today for example as a resource for managers (SunTzu \& Michaelson, 2001) and for the modern executive (Alexander and Walker, 2008). Also Hedrick (2007) re-explored Xenophone's Cyropaedia or Cyrus the Great from the point of view of war and leadership and Yamanaka and Nishio (2006) have taken the Arabian Nights and seen it form the east/west perspective.

Forbes and Prevas, (2009) on the other hand, have used ancient leaders including Sikandar and seen parallels with today's contemporary leaders. It is interesting to note here that they saw Sikandar from the point of view of his arrogance and hubris and the price he paid for it. As Forbes and Prevas (2009, p.g.10) stated very sensibly, that 'examining ancient leaders won't give us point-by-point guides that guarantee success, but it will give us real-life lessons...'that can guide organizations and help us fulfil our responsibilities.

\subsection{Scope of study}

The content used will be limited to the works of two authors of medieval Persian literature.

The first of these is the classic epic of Firdawsi written in the tenth century known as the Shahnama. Though his original work is in Persian yet translations are available and these will be analyzed. Basically four translations of the former has been reviewed.

a) The first shortened version, The Shahnama of Firdawsi version done by Alexander Rogers $(1907,2002)$ which deals about the story of Alexander pages 355 to 402

b) The second done by Arthur George Warner and Edmond Warner (vol. 6) in 1912

c) The third commonly called The Epic of the Kings by Reuben Levy (1967) (pages 232-251) and recently

d) Shahnama: The Persian Book of Kings by Dick Davis (2006, pages 441-528).

The second epic regarding Sikandar is The Sikandar Nama e Bara, also called the Sharafnameh, by Abu Muhammad Bin Yusuf bin Mu,ayyid-i-Nizamuddin commonly known in the western world as Nizami Ganjavi. He is also the writer of Laila Majnu and other works. As only one English translation is available by Captain $\mathrm{H}$ Wilberforce Clarke (reprinted 1995), this will be reviewed and if any new translation is available then that too will be incorporated in the study.

Plutarch's 'The Parallel Lives - Life of Alexander' 1919 The Loeb Classical Library Edition Volume V11 version of Alexander's childhood is also taken into consideration when assessing his narcissistic tendencies but only for comparative reasons and not as a separate or detailed study.

\section{Research Methodology}

The research question of my study is to what extent did Sikandar's childhood and early youth play a role in creating narcissistic tendencies. The content used will be limited to 
the books specified with a comparative study of Plutarch's version. The goal is not to see Sikandar as a narcissist per se but to understand whether he possessed such tendencies in childhood as depicted in the books.

\subsection{Reaching a hermeneutic phenomenological framework}

What an author/historian can say about the past is specific, focused and limited but $\mathrm{s} / \mathrm{he}$ has to acknowledge that there is more to the world than what $\mathrm{s} / \mathrm{he}$ is describing. One needs to acknowledge that history is a 'series of discourses' about the world and that the past and history are different. History encompasses what has been written/or recorded about the past whilst the past encompasses all that has happened before which may or may not be recorded by history (Jenkins, 1991. pg.5). Thus historiography refers to historians' writing, what they penned based on what they considered important. If the past and history are not one and the same, then no single description of the phenomenon is complete. Different discourses would view the same historiography with varying lenses. Though historians and others do not 'invent' one particular view, they do invent a myriad of descriptive groupings with which to read the text (Jenkins, 1991). Thus, depending on one's disciplinary base, a reader would interpret the same phenomenon differently and each would be correct as they interpret history based in their own criteria about the past. . This is reminiscent of what Orwell wrote in his novel 1984 as stated by Jenkins (1991) that 'those who control the present control the past and those who control the past control the future' (p. 18).

To analyze any literary work requires an understanding of how one goes about it. As a social science student, the primary concern was whether to see it from the perspective of literary criticism or from a sociological point of view. The analysis of choice was sociological. Sociology makes an argument that 'our identities and the way of understanding ourselves are fundamentally socially constructed and shaped, framed prescribed by social forces beyond our individual control or our individual agency' (Minwalla, 2012, Lecture). This argument postulates to a certain extent that there may be certain kinds of timeless lessons that can be learned specifically in the concept of leadership, and not only that these timeless lessons (an aspect of philosophical perennialism though this research is not espousing this concept in its totality) can be learned by reading works of literature which then give us ways to understand how we ourselves can model our behaviour on these individuals who achieved certain kinds of greatness in the context of a constructed fiction. If one is looking at it from a sociological perspective then many researches tend to follow a positivist school of thought. Yet, the sociological positivist way of looking at it is not as useful as the hermeneutic interpretive way of looking at it. What this paper is looking for is that the hermeneutic phenomenological way, which is also a branch of sociological thinking, sees sociology as an interdependent discipline. One can no longer think of sociology as distinct from the cultural practices.

It was Kant (1964) who first made this distinction that the things that we can say about the world are distinct from the world itself. This also means that it is fundamentally a phenomenological perspective. 'It is through the multiple uses of language through multiple theoretical frames that we arrive at some kind of fractured but composite picture of this globe or this universe that we live in, the things that we do in it and the people that surround us and the formations within which we function or operate' (Minwalla, 2012,).

\subsection{Theory}

This research considers both the theory and the method employed to conduct it. A multidimensional approach is used for the study. From the point of view a research design, a phenomenological perspective is kept in mind. The concept that people can be certain about 
how things appear to themselves and their consciousness creates a basis for this study (Eagleton, 1983; Fouche, 1993). For such a study the positivist method would not be suitable. Phenomenology deals with the essence of anything and as such the essence of Sikandar's childhood and youthful experiences is analyzed. Phenomenology's main aim is the return to the essences. This is portrayed by the slogan or maxim which Husserl followed was ' $\mathrm{Zu}$ den Sachenselbst' or back to the facts or things themselves (Husserl, 1911, p.g.116; Eagleton, 1983; Kruger, 1988; Moustakas, 1994) Phenomenology offered an understanding into 'the correct comprehension of the essence of the life-world' (Husserl, 1970, p. 123). It is about understanding the conscious experience of 'what we know best, what is always taken for granted in human life, always familiar to us' (p. 123). For Giorgi, (1985) (also cited in Stones, 1988) the key word in phenomenological research is 'describe'. The researcher therefore needs to describe as accurately as possible the phenomenon, without resorting to any pregiven framework, but remaining true to the essence. Thus at first a systematic reading of the phenomena is undertaken and later a description of emergent structures will be conducted. Though Giorgi's work is concerned with for e.g. emergent psychological structures, this research will incorporate other structures. Thus as a researcher, using the phenomenological method, this research is more concerned with the lived experiences of the subject under study (Kvale, 1996; Greene, 1997; Holloway, 1997; Van Manen 1997; Kruger, 1988; Robinson \& Reed, 1998; Maypole \& Davies, 2001). Sikandar's experiences are part and parcel of this study. Apart from this an interpretive hermeneutical method is used to see the text. The interpretation of text is to be carefully analyzed. It constitutes the process of understanding. The concentration can be on the historical meaning of the experience and the effects on the individual and/or the social levels (Polkinghorne, 1983); as understanding the phenomena through language (Annells, 1996); or even the study of human cultural activity as texts so as to interpret and find the expressed and intended meanings ((Kvale, 1996).

\subsection{Method}

Van Manen's (1990) approach has been used as a basis on which this study has been conducted. Phenomenology for Van Manen, is the study of the lived experience or the 'lifeworld - the world as we immediately experience it, pre-reflectively rather than as we conceptualize, categorize or reflect on it" (Van Manen 1990 pg. 9). In other words phenomenology deals with how individuals see phenomena of their own experiences, of their own consciousness and therefore is 'not introspective but retrospective'. It is what appears to the consciousness which becomes the essence. Thus one came to the point of how both phenomenology and hermeneutics can be fused as part of this research. Firdawsi and Nizami were humanistic poets who wrote their epics as commissions for his respective rulers. They narrated bygone events to please their monarch's or leaders. They narrated these events and gave a world view of Sikandar through stories and anecdotes, but, with it, they also gave their experiences, their world view; their personal, political and psychological and religious views. It is this world view that is of interest, in part, to this research.

For the researcher in any 'hermeneutic interview', (Van Manen, 1990) one needs to keep the research open and one needs to go to the 'substance' of the phenomenon being questioned. The seven points are enumerated verbatim below from Van Manen 1990 book unless otherwise stated:-

1. 'Story provides us with possible human experiences' (Van Manen 1990) or 'the reality of imaginable human experience' Van Manen 1985; pg1)

2. 'Story enables us to experience life situations, feelings, emotions and events that we would not normally experience'. (The researcher [in this case myself] too lived 
through the story and went into a different era which would not have been possible otherwise.)

3. 'Story allows us to broaden the horizons of our normal existential landscape by creating possible worlds;'( the researcher i.e. myself went into not only Sikandar's life world but saw Sikandar through the lens of two writers)

4. 'Story tends to appeal to us and involve us in a personal way;

5. 'Story is an artistic device that lets us turn back to life as lived, whether fictional or real;' (Realized that all accounts of Sikandar as stated by different authors, no matter how authentic, would definitely have elements of fiction and the authors' own personal outlook on what they perceive the character to be)

6. 'Story evokes the quality of vividness in detailing unique and particular aspects of a life that could be my life or your life;' (Re-realized people re-read history to either give explanations to current situations and make sense of their present lifeworld)

7. 'Great novels or stories transcend the peculiarity of their plots and protagonists, etc., which makes them subject to thematic analysis and criticism.' (Thus themes were isolated and later criticized)

Thus a phenomenological reading is not just a criticism of reading anything but to experience and gain a personal response which definitely comes before criticism. It is to encounter the story or stories and live through that experience to gain unique insights into what any particular text may offer. It is to muse and reflect and ponder and re-reflect on the events and characters and the poetic artistry of the writer. Thus the researcher is both the reader and the spectator. For Van Manen (1990) human science research can be and is equally 'rigourous' but the only difference is that it has the 'courage' and 'resolve' to stand apart for its 'uniqueness', that is, it is research with the soul. To go further, hermeneutic phenomenology therefore wishes to find the world as it is. There are no artificial situations that other sciences resolve to, as with experimental and other social sciences. Thus Van Manen's (1990) hermeneutic phenomenology offered the most feasible approach for this study because it was compatible with the purpose and results required for the research (Lopez $\&$ Willis, 2004). Van Manen (1990) wrote that the goal of the phenomenological researcher is action sensitive knowledge.

Thus, keeping in view this essential difference Van Manen's (1990) three pronged approach to this lived experience is used.

a) The wholistic or sententious approach where the text as a whole was viewed. Firdawsi and Nizami and their Sikandar, was reviewed in the first reading.

b) On the next readings, a selective or highlighting approach was adopted and the researcher discovered what statements or phrases seemed essential. Two more readings were conducted to come to such conclusions. Then such phrases or terms were highlighted and/or underlined. Then initial themes in the text were discovered.

c) In the detailed reading approach this research looked at every sentence of the text or a cluster of sentences and the researcher tried to understand what it revealed about the phenomena. As each text was re-read a number of times this research tried to find out what the author was trying to divulge to the reader. Phenomenology deals with the essences and so the research tried to discover what Firdawsi/Nizami had to divulge about the character. Questions as to what the authors might be thinking were asked time and again. At this stage one had to be extremely careful not to try and see 
the text from the 21st century point of view but go back in time many centuries. The next step according to Van Manen (1990) was to undergo hermeneutic phenomenological reflection. As this research is a lived experience, this research tried to discern what themes recur as commonalities. Firdawsi and Nizami's text underwent systematic and rigorous lived experience. Thus the research evolved what the term narcissism means in the Life of Sikandar via Firdawsi and Nizami.

Apart from this, as this is a study of narcissism, a summary of narcissism in childhood and early adulthood was reviewed. However narcissism in childhood/ adolescence is not a new phenomenon and much analysis and research has been conducted in the area.

\subsection{Narcissism in Childhood/Adolescense}

The developmental course of narcissism in childhood to date has not been completely understood and though much research is available yet many areas are still unresearched. Despite this the literature is quite extensive and takes into account empirical research and clinical observations. Some self-report narcissism scales studies have been developed (Thomaes, Stegge, Bushman, Olthof, \& Denissen, 2008) and a recent study on preschool personality precursors (Carlson and Gjerde, 2009). There is evidence that children can be reliably assessed as young as 3 years and that the personality characteristics which are measured at that age have long term implications (Caspi, 2000). The DSM-IV (American Psychiatric Association, 2000) has also proposed that personality disorders maintain their stability and the onset can be traced to early childhood (Shiner, 2005). This however does not mean that having certain narcissistic characteristics do always develop into full blown narcissistic personalities or that narcissism has fully developed it-self at that young an age, but that such early characteristics can lead to and culminate in some having narcissistic orientations in later life.

Some narcissistic tendencies that are said to develop in early childhood can include the need in children to be the center of attention or high level of activity, histrionic tendencies, impulsivity, and an antagonistic interpersonal stance. The concept of grandiose self-developing in early life due to social interactions at that time has led to the same concept in later life and reinforces this high sense of self. Thus one is the precursor of the other (White, 1980; Kernberg, 1986b; Raskin et al., 1991). At the same time histrionic tendencies are a part and parcel of this attention seeking attribute that's part of their childhood. Some researchers have emphasized the impulsivity as also a main feature of early narcissism (Raskin et al., 1991; Wink, 1996; Vazire \& Funder, 2006). For many this aspect has biological connotations and lack of control over ones impulses then leads to such behavioural attitudes later on. Apart from this, antagonistic behaviour is also a part and parcel of such tendencies especially of children towards their peer groups and leads to narcissistic tendencies later on (Raskin et al., 1991). For some researchers ego threats in children leads to aggressive attitudes and leads in turn to hostile behaviour from others which in turn reinforces the child's behaviour in sense justifying it and leads to a downward spiral (Bushman and Baumeister, 1998).

Maccoby (2003) states that a crucial difference between those with narcissistic tendencies and other personality types is that such children do not subscribe to or internalize their parents or peer group and as such do not have to go against any inner voice. When stating such a concept we are not speaking of those children who are gifted and as such cannot identify with their parents. The family dynamics of the former for Maccoby can be referred to as the Stephen King scenario with 'a strong supportive mother and an absent or failed father.' In such circumstances the child does not have strong male figure head 
especially a boy who can be a positive presence and being free from 'paternal domination' or someone to simply look up to, he goes to the supportive mother. Such family dynamics among narcissists is extremely interesting. Maccoby gives interesting examples in the historical context with well-known people like Jim Clark, John D Rockefeller, Leonardo da Vinci and others. He goes on to state that at times a parents own frustrated ambitions and dreams are transferred to the son and that such tendencies put pressure on the child.

Thus seven areas of narcissism mentioned above are going to be assessed namely grandiose self, high levels of activity, histrionic tendencies, impulsivity, antagonistic interpersonal stance, strong supportive mother and frustrated ambition of parents.

\subsection{Childhood narcissistic tendencies of Alexander in the Persian texts.}

Though these precursors do exist and have been researched, this paper is focusing on texts of Firdawsi and Nizami.

Thus though all the seven parameters discussed above are dealt with when discussing the early life of Sikandar or Alexander in the Persian texts, with referencing of Plutarch's version, some texts have slightly more details about Sikandar's early life whilst others have sketchy accounts.

The question here arises as to why these seven parameters have been chosen as a basis of this study. When reading about Alexander from non -Persian sources, Plutarch's name was mentioned in a number of texts. Thus I choose this writer as a background source and for comparative analysis. When reading Plutarch's version seven aspects of childhood narcissism were evident. Thus these became the basis of the study.

In reading Plutarch, the latter explains that he is not writing history but lives and as such 'a slight thing like a phrase or a jest often makes a greater revelation of character than battles when thousands fall, or the greatest armaments, or sieges of cities' (Loeb edition, 1919, pg 225). Thus the exploits of Sikandar will not be the focus but his character and in this case his narcissistic tendencies will be the subject of choice.

A short outline discussing narcissistic elements out here would not be amiss. Alexander's lineage via his father Philip is with Heracles and through his mother Olympias, Aeacus, so a sense of grandiosity would naturally develop with such ancestry. As a child Plutarch calls him impetuous and violent on the one hand yet he had great self restraint too. Once when asked if he would contest in a race, Alexander stated that only if Kings were part of it. So from the beginning his sense of worth was pretty high. Impulsivity is evident in the story of acquiring his horse Bucephalas which no rider wanted to train but at that young age Alexander took up the challenge. Also Alexander was never glad to hear that his father had won battles or cities. It may be said that he was jealous of his fathers achievements and felt that nothing important enough would be left for him to achieve. This proves an antagonistic interpersonal stance and the effects of an absentee father. His first former close relationship with Aristotle which reduced with time shows that if minds did not meet then Alexander felt antagonism. Also Alexander learnt as much as he could both from travellers who came to his fathers kingdom as well as his teachers. This high level of activity both physical and intellectual is evident in what ever he did. His own personal life too was in constant ups and down especially since Olympias his mother was jealous and upset of the fact that Philip married a number of times and would produce an heir who might challenge Alexander claim. Thus, often was Alexander used as a tool for his mother's own power and constant battles raged between father and son. This strong supportive but jealous and sullen mother figure must have had a strong and lasting impact on his psyche. One histrionic tendency, which 
Plutarch does mention, occurs later on when Philip married Cleopatra whose uncle was Attalus. Drunk, when the latter toasted for a legitimate Macedonian heir, Alexander asks whether he then should be taken for a bastard. When Philip intervenes and falls down Alexander scathingly remarks that this is the man who plans to invade Asia when he is not even steady enough to move from couch to couch.

Such examples in Plutarch's text do show that Alexander had a somewhat troubled childhood and youth which may have given rise to some narcissistic tendencies.

The important aspect here to remember when analysing any character is to understand the dynamics and external influences that bade the character what he or she is and to understand the character of a larger than life person in this case Sikandar (Alexander) is definitely not an easy job. Thus at first it is important to focus on the background or for that matter the ancestry of this larger than life figure. The Persian Epics both Firdausi's Nizami's and have different stories regarding his birth which in turn are different from the Greek versions.

\subsection{Firdawsi's version}

Firdawsi's version states that Alexander was actually the son of the Persian King Darab and that Filicus of Rum (Philip of Macedon) was his maternal grandfather. The story goes on to state that as Filicus and Darab had three ferocious but inconclusive battles Filicus sent emissaries to Darab for peace. The King Darab agreed in return for the hand of Filicus's daughter Nahid who 'shineth mid the others like a signet,' and of 'cypress height and springlike cheek' (Warner and Warner, 1912, pg 24). Apart from this, as tribute, Filicus should also send a hundred thousand eggs of gold, in each of which a royal gem of price should be placed.

The Greek princess was married to Darab but the story takes on a wondrous twist where one night the Queen emitted pungent breath and Darab was disgusted with it. Though some physicians pounded some herbs (Sikandar) and cured her breath, she was sent home to Rum to her father. Little did Darab realize that the Queen whom he was rejecting was pregnant with his child- his son.

Filicus did not want to reveal that his own daughter had been sent home as it would be termed as an insult, 'Darab hath put away my child' (Warner and Warner, 1912, pg 26) and when the princess returned, he claimed the child as his own by one of his wives, 'There hath appeared a Cesar of my seed' (Warner and Warner, 1912, pg 26). Thus according to this Persian Myth Sikandar and Dara (whom he later fought were actually half brothers) and the throne Sikandar claimed was legitimately his own. However no mention at this stage is made whether Sikandar knew of his Persian ancestry. However in the later part of the story Sikandar acknowledges that he knew about his origins.

This in turn has allowed Sikandar to be a part of national epics as a hero and the legitimate heir to the Persian throne. Curtis, (1993) states that to legitimize Sikandar may have been a 'political necessity' (pg 57) as only 'rulers with a genuine right to kingly glory were chosen to rule over Iran' (pg 57). As a foreigner would have no right or place in the history of that nation, being the half brother of the then Iranian King Dara would automatically qualify his right to the throne.

In a slightly different Persian version called Iskandarnamah (The Book of Alexander ) by an anonymous $12^{\text {th }}$ to $14^{\text {th }}$ century writer translated by Southgate (1978) follows Firdawsi's version of Sikandar's heritage but states that Sikandar knew that he was son of Darab but 'kept the truth concealed' (pg 10). 
It is interesting to note here that knowing that he had been rejected by his own father and though loved by his grandfather would make any body embittered.

The concept of grandiosity and the sense of grandiosity in children is a very important aspect which may lead to narcissistic tendencies. Firdawsi's Sikandar and the story of his birth is not absent of this important theme and his birth was regarded to as to come on an auspicious occasion. Just when the Princess was giving birth a brown mare in Filicus's stable who was strong and swift gave birth to a foal all white (Warner and Warner, 1912) or grey (Firdawsi and Davis, 2006), 'short-shanked and breasted like a lion' (Warner, 1912, pg 26). Cesar was extremely happy and felt that such an incident boarded well for him and Rum and was a lucky sign.

It would therefore not be surprising that Sikandar did develop his sense of grandiosity from an early age where he was cherished and feted. Firdawsi goes on to say that due adornments were giving to Sikandar who in turn was heir apparent to Filicus. The latter treated him more attentively than a son and dressed him in the robes of a champion. He grew up to be wise, 'became adroit, intelligent, grave in his manner and knowledgeable...learned the arts of kingship...' and learned the art of administering the empire and to learn to be a king. (Firdawsi and Davis, 2006, pg 455)

It is interesting to add here that Firdawsi for his stories on Sikandar used two different sources at least. In the main section where the story of Sikandar (Alexander) is presented the latter is portrayed as an Iranian prince with legitimate claim to Divine Glory. Yet, when writing about the Sassanian period, he scathingly speaks about Sikandar and describes him as an enemy of Iran, as evil as Zahhak and the usurper of the Divine throne and condemns him (Curtis, 1993). This aspect is important to remember when discussing as differing sources or circumstances would give differing images of the same and one needs also to remember that Firdawsi wrote the Shahnameh over decades and rereading or reviewing over 50000 couplets would have been quite impossible.

\subsection{Nizami's version}

For Nizami the story is slightly different. Yet the same concept of grandiosity surrounds Alexander's birth. Nizami apparently takes a more philosophical view of Sikandar's rule and the later is portrayed as the 'ultimate and perfect ruler' (Curtis, 1993, pg. 57) who took 'the path of truth' (Nizami and Clark, 1995, pg 133).

In Nizami's Canto XV, he basically gives two different versions of the birth of Sikandar (Alexander) though he does state that there are many more.

In the first version Alexander is not the son of Philip but the son of an ordinary woman 'wife of a devotee' (pg 137) who pregnant with her child, and in distress had left her husband and town. She apparently gives birth to the child among some ruins and dies leaving the child unattended. Faylikus, (Philip of Macedon) passing through the area comes across this baby which 'sucked its own finger, bit its own thumb for its mother' (pg 138). Faylikus takes the baby and raises him as his own heir. Nizami comments that this story has no truth to it and reinterates that the story of Sikandar being the son of Dara has no truth too, 'in foolish speech, was no correctness,' (pg 139)

In Nizami's second version of the birth, a more romantic element is evident. Philip falls in love with 'an idol...in appearance, auspicious; in stature tall...a beauty as the son in midday; the narcissus half-asleep glance making:' (pgs 139-140). When she becomes pregnant by him, Philip orders the courts wise sage to read the stars, so as to reveal any secrets the stars may foretell about the unborn child. The stars reveal that a strong, brave and 
victorious child would be born with the absence of 'the evil eye' (pg 143) who would hold the key to the world and that 'the garden became illuminated by such a plant...they established his name Sikandar, the king' (pg 143). There was much rejoicing with the royal birth.

As soon as Sikandar could walk, he desired a bow and arrow from his wet nurse practicing target shooting on paper or on silk. Once he was slightly grown, he takes up the sword, fighting with the lions. He pursued all the paths of kinship, 'royalty and sovereignty' by being excellent at horse riding and learns the skills of warfare, as tutoring of the royal role he was to assume. As such the concept of being grandiose and being able to do much at a young age is evident in the writings of Nizami. It is important to remember here that individuals have an intrinsic need to have and maintain a positive sense of self.

The next Canto is devoted to the instruction of Sikandar by the sage Lukumajish, the father of Aristatalis (Aristotle). Sikandar was taught kingly manners and all the arts, which would enlighten his mind whereby he would be able to recognise the truth. He was taught new subjects, about the mystery of the world and the new sciences. Lukhmajish's own son Aristatalis too studied with the Prince and the latter had given his heart to Sikandar.

Nizami goes on to say that when Sikandar's fortune was being given, he, Lukhmajish had inscribed within it his own son Aristatalis name and now consigned his son to Sikandar. He informs the prince that when he leaves the school and goes to the battle field, he asks Sikandar to 'bring the heads of the enemy to the earth', and to bring the world 'beneath the seal of the seal ring,' (pg 148) so as to acquire tribute from seven climes or regions of the world. He asks the Prince to be sovereign over the vast areas, but advises Sikandar not to 'adore' the spoils of war namely gold and silver, and to heed the advice of Aristotle.

He goes on to say that a wise minister is better than all property or treasure of the world and that as Sikandar's horoscope and ally is great fortune, his son's ally is skill. Each of these that is fortune and skill complement each other and that one is the half or helper of the other. Sikandar gives his word to the sage and promises to obey and listen to Aristatalis' judgment and asked God to be the witness of such an oath.

Lukumajish knew that Sikandar was battle hungry and wanted to vanquish the 'arrogant ones', so as a protective measure he drew the 'Abjad', an arithmetical device in which Sikandar would write his own and his adversaries name and to calculate the score as advised by his teacher. Before planning for battle Sikandar was asked to always use this device and only if his name is the conqueror of the circle, to fight or otherwise his enemy would be more powerful and win the battle. Sikandar liked the device and later used it as a tool to see whether he would be successful.

Sikandar thus acquired knowledge and became a 'cauldron of every art' ready for use (pg 150). For the smallest of ventures he used Aristatalis's advice and asked his opinion. After the passage of time Filicus died and took 'his chattels from the world,' and Sikandar ascended the throne.

Nizami then gives analysis of life and death. He calls the world as a tree of six sides and four roots and some people are bound to its four roots. He speaks that with time, each leaf falls and that each person sports only a single breadth. As one fruit dies another takes its place, meaning as one dies another is born. Whether man is willing or not he has to pass on. It is here that he, Nizami questions as to why people are so full of self-interest, and though death awaits them, they are still self-seeking. He hopes that man can escape from this self seeking snare. He speaks of self worshipping as something dark. He asks for wine as a release 
from himself and self interest and asks for 'luminosity'. The wine would release him from the troubled world and would bestow lightness to him.

\subsection{Analysis/Discussion}

It is interesting to note that both versions of Persian texts regarding Sikandar's childhood and youth are quite different from the Greek texts, though some similarities do exist. One point on which both are consistent is that in Sikandar's life, the concept of grandiosity existed which would invariably lead to high self esteem. As stated earlier, grandiosity emerges early in childhood ((Kernberg, 1986b; Raskin et al., 1991; White, 1980). Naturally being brought up in as heir apparent would result in an inflated sense of self. In all three texts, Sikandar's birth was regarded as out of the ordinary. In the Greek myths he had ancestors like Hercules and his birth was regarded as auspicious, with many signs all signifying that he would be extraordinary. For Firdawsi, he was actually the son of the ruler of the largest kingdom of the time namely Dara whist Nizami too foretold a glorious future. For some theorists, narcissism is not something that is stable from day one or one based on the concept of individual difference. It is a personality process, something that is 'constantly under construction' (Morf and Rhodewalt, 2001, pg 180). A precursor like grandiosity which leads to an inflated self concept may gradually solidify over time, due to other interactive processes. Excessive self-esteem (e.g., Kernis, 2003) may in turn lead to fragile and unstable self-esteem (e.g., Rhodewalt, Madrian, \& Cheney, 1998), grandiosity as stated here (e.g., Raskin et al., 1991), and a defensive self-enhancement which may lead to egoism (e.g., Campbell, Rudich, \& Sedikides, 2002; John \& Robins, 1994; Paulhus \& Williams, 2002). Thus though no obvious elements of narcissism were visible via the texts in his childhood, yet a precursor like grandiosity was apparently present.

As stated earlier another precursor in childhood which may lead to narcissistic tendencies is high levels of activity and impulsivity. All three texts to a certain extent depict either one or both the traits. The Greek text speaks of Sikandar's impulsivity when acquiring Bucephalas whilst the Persian texts especially Firdawsi's Shahnama has not much detail as to his impulsivity. However there is enough information to tell us that he learned all the aspects of kingship from the best teachers to look after his kingdom and to found an empire. Nizami's version does give details as to Sikandar's target shooting and fighting with the lions, which shows his heroic imagery as well as his impulsivity and his high levels of activity. Impulsivity at times has been regarded as something at the core of narcissistic personality in childhood (Vazire and Funder, 2006). Thus, this refusal to act consciously is interrelated to the concept of the inflated self and the defences one adopts, to this self view. The end result is that they do not consciously deliberate over their actions ((Diamond \& Blatt, 1994). However, Nizami warns the young Sikandar to be wary of inflated self, which comes with the ability to do all, and warns Sikandar that such a fall is quite common and that he should be beyond all such things which in turn would make him be simply that to which Sikandar promises. Nizami too gives a sermon on how fleeting life on earth is and wonder and ponders as to why people strive relentlessly for fortune and the egoistic self. Thus it is interesting to note that centuries ago Nizami spoke of narcissism as something dark and destructive.

Antagonistic interpersonal stance is another feature of narcissism in childhood (Raskin et al., 1991; Warren et al., 2002). Plutarch's text does show this aspect particularly with relation to his father. The fact that Sikandar was consistently jealous of his father's achievements and could not tolerate any favourable comment on it, as such, is proof of this aspect. Hostile relations are a much researched aspect in narcissism (e.g., Bushman \& Baumeister, 1998; Smalley \& Stake, 1996; Twenge \& Campbell, 2003). Sikandar's narcissistic and inflated self was challenged and it is possible that the real issue was a sense of 
fragmented self. Recent research proves the latter point (Stucke \& Sporer, 2002). Yet Firdawsi's and Nizami's version shows no such aspect in his childhood and adolescence.

On the point of view of a strong supportive and also an ambitious mother, one cannot deny Olympias influence in Plutarch's version. Olympias's own fears were transferred to her son especially in account of Sikandar not being heir apparent to Philip. She imbibed in the young Sikandar that he was special and par excellent, creating a socialized psyche. A narcissistic mother naturally requires a 'perfect child to mirror her perfection as a giver and nurturer of life' (Hotchkiss, 2003). Signs of narcissism are evident before the child is born (Hotchkiss, 2003). All three versions depict this to some extent with the Greek text being more vocal to this aspect. However, the Persian texts differ in the sense that it's not the mother but the male parent who asks the soothsayers and astrologers to predict whether the perfect child is going to be born. In the Greek version it is Olympias who gives and imbibes in Sikandar all his grandiose fantasies whilst in the Persian texts this concept is missing. Such mothers have 'excessive expectations' of themselves and others (Hotchkiss, 2003) but as the bond between the mother and child loosens, as the child grows, her own obsessiveness has a detrimental effect on the child. She wants to hold on to him in whatever way possible and this is extremely evident in Plutarch's versions.

In all three versions of the texts, the concept of the 'Pseudo mature' child is encapsulated where the child skips childhood and learns to behave in a more grownup manner (Hotchkiss, 2003). Thus, children who are given such childhoods have not been given the skills to deal with managing shame, rage and aggression and the unresolved infantile narcissism therefore would act as a precursor to adult narcissistic tendencies (Hotchkiss, 2003). In all three texts, from his childhood Sikandar has had to be the young adult, the best, the heir apparent and skilled at all he does. Thus, it is a possibility that such children who grow up may be least capable of dealing with many issues.

\section{Conclusion}

As reiterated earlier, the study was a discursive one on narcissistic tendencies in childhood and adolescence and that such inclinations are not necessarily a precursor to adult narcissistic predispositions. In the two Persian texts, which themselves were a fusion of myth and reality, a few narcissistic traits like the grandiose self and high levels of activity and some impulsivity is evident but that does not conclude that Alexander/Sikandar childhood was one where narcissistic tendencies were paramount. As this study is a preliminary one to a larger study on leadership, it will be interesting to see if such precursors do indicate and do predict the fact whether Sikandar was truly depicted as a narcissist in the Persian texts. Thus one can effectively state that moral ambivalence resonates in the texts of both Firdawsi and Nizami. Yet, at this point in time the indicators of surety towards adult narcissism are too ambivalent

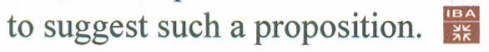

\section{References}

Alexander G., and Walker T J., 2008, Sun Tzu: The Art of War for the Modern Executive, Yamazato Publications.

American Psychiatric Association, 2000, Diagnostic and statistical manual of mental disorders (DSM-IV-TR-4th edition, Text Revision) American Psychiatric Association, Washington, DC: International Research Journal of Applied and Basic Sciences, Vol, 4 (8): pg. 2389-2392

Annells M., (1996), Hermeneutic phenomenology: Philosophical perspectives and current use in nursing research. Journal of Advanced Nursing, 23, 705-713. 
Berelson, B., (1952) Content analysis in communication research, Free Press, Glencoe, IL

Borza E N., 1998, Multimedia: Alexander's Epic March, Archeology, Vol. 51 No3, (http://www.archaeology.org/9805/etc/multimedia.html)

Bose Partha, 2003, Alexander the Great's art of strategy, Penguin Books, India

Bosworth S. B., 2000, Alexander the Great in fact and fiction, Oxford University Press, UK

Brunwasser M., 2011, Weary of Greek Pressure, Macedonia Claims a Hero, Skopje Journal, in The New York Times, [http://query.nytimes.com/gst/fullpage.html?res=950CEEDA1530F937A35754C0A9679D8B 63\&ref-alexanderthegreat; (retrewied 28sept,2012)]

Bryman Alan, 2004, Social research methods, Oxford University Press, Oxford

Bushman, B. F., \& Baumeister, R. F., 1998, Threatened egotism, narcissism, self esteem, and direct and displaced aggression: Does self-love or self-hate lead to violence? Journal of Personality and Social Psychology, 75, 219-229.

Carlson K S., and Gjerde P F., 2009, Preschool personality antecedents of narcissism in adolescence and young adulthood: A 20-year longitudinal study, Journal of Research in Personality, 43, 570-578

Campbell, W. K., Rudich, E. A., \& Sedikides, C., 2002, Narcissism, self-esteem, and the positivity of self-views: Two portraits of self-love. Personality and Social Psychology Bulletin, 28, 358-368

Cartledge P., 2005, Alexander the Great, Vintage Books, USA

Caspi, A., 2000, The child is the father of the man: Personality continuities from childhood to adulthood. Journal Personality and Social Psychology, 78, 158-172

Curtis V S., 1993, Persian Myths, The British Museum Press, U K

Diamond, D., \& Blatt, S. J. (1994), Internal working models and the representational world in attachment and psychoanalytic theories. In M. B. Sperling \& W. H. Berman (Eds.), Attachment in adults: Clinical and developmental perspectives (pp. 72-97), The Guilford Press, New York

Davis Dick, 2006, Epic and sedition: the case of Ferdowsi's Shahnameh, Mage Publishers, Washington DC

Eagleton, T. (1983). Literary theory: An introduction, Basil Blackwell, Oxford

Ellis, H. (1898). Auto-eroticism: A psychological study. Alienist and Neurologist, 19, 260-299

Firdawsi 1912, Books of Kings, Trans, A G Warner and Warner E., Ballantine Hanson and Co. London

Firdawsi., 1967, The Epic of the Kings, trans. R. Levy, London

Firdawsi, 2006, The Shahnameh: The Persian book of Kings, Trans, Dick Davis, Viking, U S

Firdwsi, 2002, The Shah-Namah of Firdawsi, trans. Alexander Rogers, Saang -e meel publications, Lahore

Forbes S., and Prevas J., 2009, Power Ambition Glory, Crown Business, New York 
Fouche, F. (1993). Phenomenological theory of human science. In J. Snyman (Ed.), Conceptions of social inquiry (pp. 87-112).: Human Science Research Council, Pretoria, South Africa

Freinhar, J. P., 1986, Oedipus or Odysseus: Developmental lines of narcissism. Psychiatric Annals, 16, 477-485.

Freud, S. (1931/1950). Libidinal types. Collected papers, Vol. 5. Hogarth Press, London

Giorgi, A., ed. Phenomenology and Psychological Research. Pittsburgh: Duquesne University Press, 1985

Greene, M. (1997). The lived world, literature and education. In D. Vandenberg (ed.), Phenomenology \& education discourse (pp. 169-190). Heinemann, Johannesburg:

Hedrick L. (Ed), 2007, Xenophon's Cyrus the Great-The arts of leadership and war, St Martins Press, New York

Holloway, I. (1997). Basic concepts for qualitative research. Blackwell Science, Oxford:

Hotchkiss Sandy, 2003, Why Is It Always About You: The seven deadly sins of narcissism, Free Press, New York

Husserl, E., 1970, The crisis of European sciences and transcendental phenomenology. (D. Carr, Trans.). Evanston, IL: Northwestern University Press. (Original work published 1954)

Jasnow R., 1997, The Greek Alexander Romance and Demotic Egyptian Literature, Journal of Near Eastern Studies, Vol. 56, No. 2, (Apr., 1997), pp. 95-103

Jenkins Keith, 1991, Re-thinking History, Routledge, New York

John, O. P., \& Robins, R. W. (1994) Accuracy and bias in self-perception: Individual differences in self-enhancement and the role of narcissism. Journal of Personality \& Social Psychology, 66, 206-219.

Kant Immanuel,1964, The doctrine of virtue. Part II of the Metaphysic of morals, Harper \& Row, New York

Kernis, M. H., 2003, Toward a conceptualization of optimal self-esteem. Psychological Inquiry, 14, 1-26.

Kernberg, O. F. (1986b). Further contributions to the treatment of narcissistic personalities. In A. P. Morrison (Ed.), Essential papers on narcissism (pp. 245-292),New York University Press, New York

Kernis, M. H. (2003). Toward a conceptualization of optimal self-esteem, Psychological Inquiry, 14, 1-26

Kohut, H.,1978d, Forms and transformations of narcissism. In P. Ornstem (Ed.), The search for the Self, New York: International Universities Press. (Original work 1966)

Kohut, H., 1971, The analysis of the Self. New York: International Universities Press.

Kruger, D. (1988). An introduction to phenomenological psychology (2nd ed.). Cape Town, Juta, South Africa:

Kvale, S. (1996). Interviews: An introduction to qualitative research interviewing, Sage, Thousand Oaks, CA 
Lopez, K.A., \& Willis, D.G., 2004, Descriptive versus interpretive phenomenology: Their contributions to nursing knowledge. Qualitative Health Research, 14, 726-735.

Maccoby M., 2003/ 2007, Narcissistic Leaders- who succeeds and who fails, Harvard Business School Press, U S A

Maccoby, M. (2004). The productive narcissist: The promise and peril of visionary leadership, Broadway Books, New York

Malbari N and Dr. Jalbani, 'Self Love: Narcissistic Leadership in Film-Othello and Omkara', Journal of Independent Studies and Research, Vol. 6 No2. July 2008.

Marshall C., and Rossman G B., 2006, Designing qualitative research, Sage publications, New Delhi

Martino L P., 2008, Leadership and strategy: Lessons from Alexander the Great, Book Surge Publishing, US

Maypole, J., \& Davies, T. G. (2001). Students' perceptions of constructivist learning in a community college American History II. Community College Review, 29(2), 54-80.

Minwalla F., 2012, (Personal Lecture)

Morf, C., \& Rhodewalt, F. (2001) Unraveling the paradoxes of narcissism: A dynamic selfregulatory processing model. Psychological Inquiry, 12, 177-196.

Moustakas, Clark. 1994, Phenomenological Research Methods. Thousand Oaks, Ca.: Sage Publications,

Nizami., 1881, 1995, Sikandar nama e Bara, Trans. H Wilberforce Clarke, Low Price publications, New Delhi

Omidsalar Mahmoud, 2011, Poetics and Politics of Iran's National Epic, The Shahnameh, Palgrave Macmillan, USA

Omidsalar Mahmoud, 2012, Iran's Epic and America's Empire, Afshar Publishing, USA

Pawson Ray, 1995, Methods of content/document/media analysis in Haralambos M,(ed.) Developments in Sociology, Vol. 11, Causeway Press, Ormskirk

Paulhus, D. L.,1998, Interpersonal and intrapsychic adaptiveness of trait self enhancement: A mixed blessing. Journal of Personality and Social Psychology, 74, 1192-1209.

Paulhus, D. L., \& Williams, K. M. (2002). The dark triad of personality: Narcissism, machiavellianism, and psychopathy. Journal of Research of Personality, 36, 556-563.

Pawson Ray, 1995, Methods of content/document/media analysis in Haralambos M,(ed.) Developments in Sociology, Vol. 11, Causeway Press, Ormskirk

Polkinghorne D (1983) Methodology for the Human Sciences. Albany: Suny Press

Qunit David., 1982, "Alexander the Pig": Shakespeare on History and Poetry, Boundary 2, Vol. 10, No. 3 (Spring, 1982), pp. 49-67

Raskin, R., Novacek, J., \& Hogan, R. (1991). Narcissistic self-esteem management, Journal of Personality and Social Psychology, 60, 911-918.

Riessman Dr. Catherine Kohler, 2008, Narrative methods for the Human Sciences, Sage publications Inc, United Kingdom 
Robins, R. W., \& Beer, J. S., 2001, Positive illusions about the self: Short-term benefits and long-term costs. Journal of Personality, 80, 340-352.

Robinson, D., \& Reed, V. (Eds.). (1998). The A - Z of social research jargon. Ashgate, Aldershot, UK:

Robinson C A., 1953, The History of Alexander the Great, Brown University studies, no. 16 [etc.], Brown University, Providence

Rhodewalt, F., Madrian, J. C., \& Cheney, S. (1998) Narcissism, self-knowledge organization, and emotional reactivity: The effect of daily experiences on self-esteem and affect. Personality and Social Psychology Bulletin, 24, 75-87.

Sheppard R, 2008, Alexander the Great at War: His army - His battles - His Enemies, Osray Publishing Midland House, UK

Shiner, R. (2005). A developmental perspective on personality disorders: Lessons from research on normal personality development in childhood and adolescence. Journal of Personality Disorders, 19, 202-210

Smalley, R. L., \& Stake, J. E. (1996), Evaluating sources of ego-threatening feedback: Selfesteem and narcissism effects. Journal of Research in Personality, 30, 483-495.

Stones, C. R. (1988). Research: Toward a phenomenological praxis. In D. Kruger (Ed.), An introduction to phenomenological psychology (2nd ed., pp. 141-156). Juta. Cape Town, South Africa:

Stucke, T. S., \& Sporer, S. L. (2002). a grandiose self-image is threatened: Narcissism and self-concept clarity as predictors of negative emotions and aggression following ego-threat. Journal of Personality, 70, 509-532.

Southgate Minoo S., 1978, Iskandernamah, New York

Sun Tzu and Michaelson A, 2001, Sun Tzu: The Art of War for Managers: 50 Strategic Rules, Military Science Publishing House, Beijing -China

Thomaes, S., Stegge, H., Bushman, B. J., Olthof, T., \& Denissen, J. (2008). Development and validation of the childhood narcissism scale. Journal of Personality Assessment, 90, 382-391

Twenge, J. M., \& Campbell, W. K. (2003), “Isn't it fun to get the respect that we're going to deserve?" Narcissism, social rejection, and aggression, Personality and Social Psychology Bulletin, 29, 261-272.

Vaknin Sam, 2007, Malignant Self Love: Narcissism Revisited, Prague and Skopje, USA

Vazire, S., \& Funder, D. C. (2006), Impulsivity and the self-defeating behavior of narcissists, Personality and Social Psychology Review, 10, 154-165.

Van Manen, M (1997) From meaning to method. Qualitative Health Research, 7, 345-369

Van Manen M., 1990, Researching Lived Experience: Human Science for an Action Sensitive Pedagogy, SUNY Press, New York

Warner Nicholas, 2007, Screening Leadership through Shakespeare: Paradoxes of leaderfollower relations in Henry V on film, Leadership Quarterly No. 18 pg 1-15

Weber Maximillian, 1947 (http://en.wikipedia.org/wiki/Charismatic_authority)[ret. 12.6.2009] 
Warren, J. I., Burnette, M., South, S. C., Chauhan, P., Bale, R., \& Friend, R. (2002), Personality disorders and violence among female prison inmates. Journal of the American Academy Psychiatry and the Law, 30, 502-509.

White, M. T. (1980). Self relations, object relations, and pathological narcissism, Psychoanalytic Review, 67, 3-23.

Yamanaka Y., and Nishio., 2006, The Arabian Nights and Orientalism, I B Tauris, London

One of the hardest tasks of leadership is understanding that you are not what you are, but what you're perceived to be by others. Edward L. Flom

David Olive \& Gita Piramal, The Quotable Tycoon: A treasury of business quotations, Page 114 